\title{
Molecular Structure of Aggregated Amyloid- $\beta$ : Insights from Solid-State Nuclear Magnetic Resonance
}

\author{
Robert Tycko \\ Laboratory of Chemical Physics, National Institute of Diabetes and Digestive and Kidney Diseases, \\ National Institutes of Health, Bethesda, Maryland 20892-0520 \\ Correspondence: robertty@mail.nih.gov
}

\begin{abstract}
Amyloid- $\beta(A \beta)$ peptides aggregate to form polymorphic amyloid fibrils and a variety of intermediate assemblies, including oligomers and protofibrils, both in vitro and in human brain tissue. Since the beginning of the 21 st century, considerable progress has been made to characterize the molecular structures of $A \beta$ aggregates. Full molecular structural models based primarily on data from measurements using solid-state nuclear magnetic resonance (ssNMR) have been developed for several in vitro $A \beta$ fibrils and one metastable protofibril. Partial structural characterization of other aggregation intermediates has been achieved. One full structural model for fibrils derived from brain tissue has also been reported. Future work is likely to focus on additional structures from brain tissue and on further clarification of nonfibrillar $A \beta$ aggregates.
\end{abstract}

\begin{abstract}
$A$ ggregation of amyloid- $\beta(A \beta)$ peptides in Abrain tissue is widely believed to be the root cause of neurodegeneration in Alzheimer's disease (AD) (Hardy 2006). A $\beta$ peptides are produced by a series of enzymatic cleavages of the amyloid precursor protein (APP), a transmembrane protein that is expressed primarily in neural tissue (Arai et al. 1991; Haass and Selkoe 1993). Most A $\beta$ peptides in human brain tissue are either 40 or 42 residues in length $(A \beta 40$ and $A \beta 42)$, and are typically produced in an approximate 5:1 abundance ratio but with more pronounced aggregation of $A \beta 42$ (Gravina et al. 1995). A $\beta$ aggregation is traditionally considered to be an extracellular process, although there is also evidence that $A \beta$
\end{abstract}

aggregation can occur intracellularly (Pensalfini et al. 2014).

Multiple aggregated forms of $A \beta$ have been identified (Tycko 2014). A $\beta$ peptides have nonzero solubilities in aqueous solutions, with the precise concentration of unaggregated molecules at thermodynamic equilibrium being dependent on the peptide length (e.g., $\mathrm{A} \beta 40$ vs. $\mathrm{A} \beta 42$ ), temperature, $\mathrm{pH}$, and other conditions. Typical values are well below $100 \mathrm{~nm}$ at $37^{\circ} \mathrm{C}$ and pH 7 (Brännström et al. 2013; Qiang et al. 2013). At $A \beta$ concentrations above this solubility limit, the predominant aggregated structural state at thermodynamic equilibrium is the amyloid fibril (i.e., a state in which many $A \beta$ monomers self-assemble to form straight,

Editor: Stanley B. Prusiner

Additional Perspectives on Prion Diseases available at www.perspectivesinmedicine.org

Copyright (C) 2016 Cold Spring Harbor Laboratory Press; all rights reserved; doi: 10.1101/cshperspect.a024083

Cite this article as Cold Spring Harb Perspect Med 2016;6:a024083 


\section{R. Tycko}

unbranched filaments that are typically 5$10 \mathrm{~nm}$ in width and $0.1-10 \mu \mathrm{m}$ in length, and that contain "cross- $\beta$ " supramolecular structural motifs [see below]). Transmission electron microscope (TEM) images of amyloid fibrils are shown in Figure $1 \mathrm{~A}-\mathrm{C} . \mathrm{A} \beta$ fibrils are the main proteinaceous components of the $A \beta$ plaques that develop in $\mathrm{AD}$ brain tissue and also account for most of the total mass of $A \beta$ in brain tissue (Kuo et al. 1996; Lesne et al. 2013).
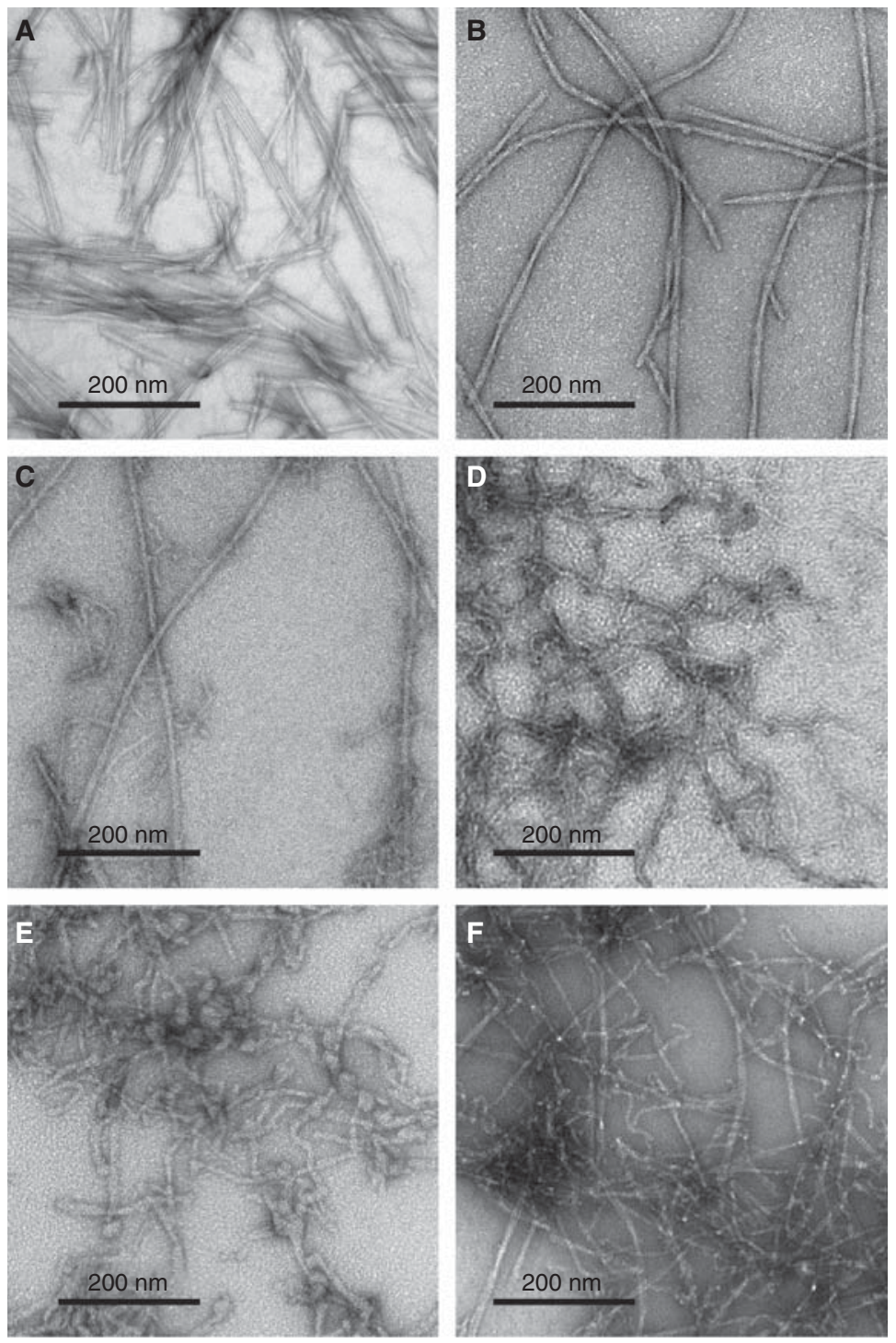

Figure 1. Negatively stained transmission electron microscope (TEM) images of amyloid- $\beta$ (A $\beta$ ) aggregates. $(A)$ A $\beta 40$ fibrils prepared in vitro with "striated ribbon" morphologies. (B) A $\beta 40$ fibrils prepared in vitro with "twisted" morphologies. $(C)$ A $\beta 40$ fibrils derived from Alzheimer's disease (AD) brain tissue and prepared by seeding synthetic $A \beta 40$ with amyloid-enriched brain extract. $(D)$ Metastable $\mathrm{D} 23 \mathrm{~N}-\mathrm{A} \beta 40$ protofibrils prepared in vitro. (E) A $\beta 40$ aggregates observed before the appearance of mature fibrils in vitro. A variety of morphologies are seen, including worm-like protofibrils and globular oligomers. $(F)$ Polymorphic A $\beta 42$ aggregates, including both fibrils and protofibrils. 
In addition to amyloid fibrils, $A \beta$ peptides can also self-assemble into a variety of oligomeric (Lambert et al. 1998; Walsh et al. 2002; Kayed et al. 2003; Lesne et al. 2006; Glabe 2008; Tomic et al. 2009; Yu et al. 2009; Sandberg et al. 2010; Ladiwala et al. 2012; Lesne et al. 2013; Liu et al. 2015) and "protofibrillar" (Goldsbury et al. 2000, 2005; Williams et al. 2005; Wu et al. 2010; Lasagna-Reeves et al. 2011) states (see below), as shown in Figure 1D-F. In experiments performed in vitro to characterize the $A \beta$ aggregation process, these oligomers and protofibrils are generally transient or metastable species, which ultimately convert to fibrils as thermodynamic equilibrium is approached. At equilibrium, nonfibrillar aggregated species have small (possibly nearly zero) populations. However, the approach to true thermodynamic equilibrium can be very slow depending on experimental conditions, so that nonfibrillar species can remain abundant for days, weeks, or even longer periods.

Considerable uncertainty currently exists regarding the identities of aggregated $A \beta$ species that are the most significant neurotoxic agents in $\mathrm{AD}$. This uncertainty arises in part from uncertainty regarding primary neurotoxicity mechanisms and also from uncertainty regarding the precise identities of $\mathrm{A} \beta$ aggregates that actually develop in $\mathrm{AD}$ brain tissue (see below). It seems possible that multiple distinct forms of aggregated $A \beta$ contribute to neurodegeneration in $\mathrm{AD}$ through multiple distinct mechanisms (Deshpande et al. 2006).

The remainder of this review focuses on the molecular structures of $A \beta$ aggregates. Detailed molecular structural information is important for several reasons: (1) as a prerequisite for a fundamental understanding of the molecular and intermolecular interactions that drive aggregation and fibril formation; (2) as a prerequisite for a fundamental understanding of relationships among the various types of $A \beta$ aggregates and the aggregation "pathway"; (3) as a basis for the development of chemical compounds that bind selectively to $A \beta$ aggregates for purposes of diagnostic imaging; (4) as a basis for the development of compounds that interact with $A \beta$ aggregates, to inhibit or retard aggre- gation, or possibly to guide the aggregation process toward relatively nontoxic species; and (5) as a basis for understanding interactions of $A \beta$ aggregates with metal ions, membrane surfaces, cell-surface receptors, or other entities that may play roles in neurotoxicity mechanisms.

Detailed structural characterization of $A \beta$ aggregates has not been straightforward because they are inherently noncrystalline and insoluble and are, therefore, not amenable to direct studies by traditional methods of X-ray crystallography and multidimensional liquid-state nuclear magnetic resonance (NMR). In addition, macroscopic samples of $A \beta$ aggregates tend to be structurally heterogeneous, and nonfibrillar species are transient or have low abundances. Nonetheless, considerable progress has been made through the application of novel solidstate NMR (ssNMR) methods (Griffiths et al. 1995; Lansbury et al. 1995; Benzinger et al. 1998; Antzutkin et al. 2000, 2002, 2003; Balbach et al. 2000, 2002; Petkova et al. 2002, 2004, 2005, 2006; Jaroniec et al. 2004; Paravastu et al. 2008; Van Melckebeke et al. 2010; Bayro et al. 2011; Qiang et al. 2012; Lu et al. 2013; Schütz et al. 2014), electron microscopy (Jiménez et al. 1999; Goldsbury et al. 2000, 2005; Meinhardt et al. 2009), hydrogen/deuterium exchange (Lührs et al. 2005; Kheterpal and Wetzel 2006; Olofsson et al. 2007), electron paramagnetic resonance (EPR) (Török et al. 2002), X-ray fiber diffraction (McDonald et al. 2012), X-ray crystallography of amyloid-like peptide microcrystals (Nelson et al. 2005; Sawaya et al. 2007; Laganowsky et al. 2012), and other biophysical and biochemical techniques (Kheterpal et al. 2001; Kodali et al. 2010; Klinger et al. 2014). For A $\beta$ fibrils, complete structural models that are based primarily on ssNMR data now exist (Petkova et al. 2006; Paravastu et al. 2008; Bertini et al. 2011; Schütz et al. 2014; Sgourakis et al. 2015; Xiao et al. 2015), including one complete model for $A \beta 40$ fibrils derived from human brain tissue (Lu et al. 2013). A detailed model of a metastable $A \beta$ protofibril has also been developed from ssNMR data (Qiang et al. 2012). Complete models for oligomeric A $\beta$ assemblies have not yet been developed, but a substantial body of experimental data has 
R. Tycko

been obtained for samples with a variety of morphologies, prepared under a variety of in vitro conditions (Chimon and Ishii 2005; Chimon et al. 2007; Ahmed et al. 2010; Scheidt et al. 2011, 2012; Lopez del Amo et al. 2012; Tay et al. 2013; Lendel et al. 2014; Sarkar et al. 2014; Huang et al. 2015; Parthasarathy et al. 2015; Potapov et al. 2015).

\section{EARLY STRUCTURAL STUDIES}

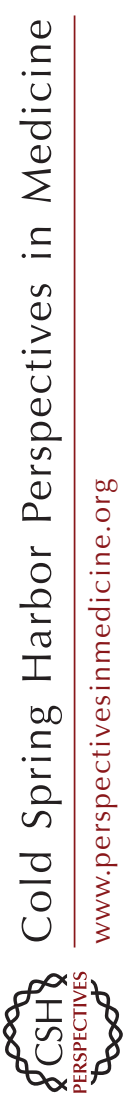

X-ray fiber diffraction data first showed that amyloid fibrils contain cross- $\beta$ structural motifs (Eanes and Glenner 1968). A cross- $\beta$ motif is one in which certain segments of the peptide or protein sequence adopt extended, $\beta$-strand conformations and assemble into ribbonlike $\beta$-sheets (Astbury et al. 1959), with the $\beta$-strands running approximately perpendicular to the fibril growth axis and with hydrogen bonds between $\beta$-strands running approximately parallel to the growth axis, as shown in Figure 2. The spacing between $\beta$-strands within a $\beta$-sheet is necessarily $d=0.47-0.48 \mathrm{~nm}$, as dictated by the fixed length of the interstrand hydrogen bonds. This well-defined spacing leads to a characteristic, sharp maximum in $\mathrm{X}$-ray scattering intensity at the angle $\theta=$ $\sin ^{-1}(\lambda / 2 d)$, where $\lambda$ is the $\mathrm{X}$-ray wavelength, directed along the fibril growth axis (i.e., in the meridional direction) in fiber diffraction measurements on aligned fibrils. In addition, the diffraction data typically show a broader maximum in scattering intensity perpendicular to the growth axis (i.e., in the equatorial direction) at a scattering angle that corresponds to a $0.8-1.0 \mathrm{~nm}$ spacing. This equatorial feature is commonly attributed to the existence of multiple $\beta$-sheet layers within the fibrils.

As depicted in Figures 2 and 3, a variety of cross- $\beta$ motifs are conceivable, comprised of either parallel $\beta$-sheets or antiparallel $\beta$-sheets, with each peptide or protein molecule contributing one or more $\beta$-strands to each $\beta$-sheet and with one or more $\beta$-sheet layers. From fiberdiffraction data alone, it has not been possible to distinguish parallel $\beta$-sheets from antiparallel $\beta$-sheets, to determine the identities of

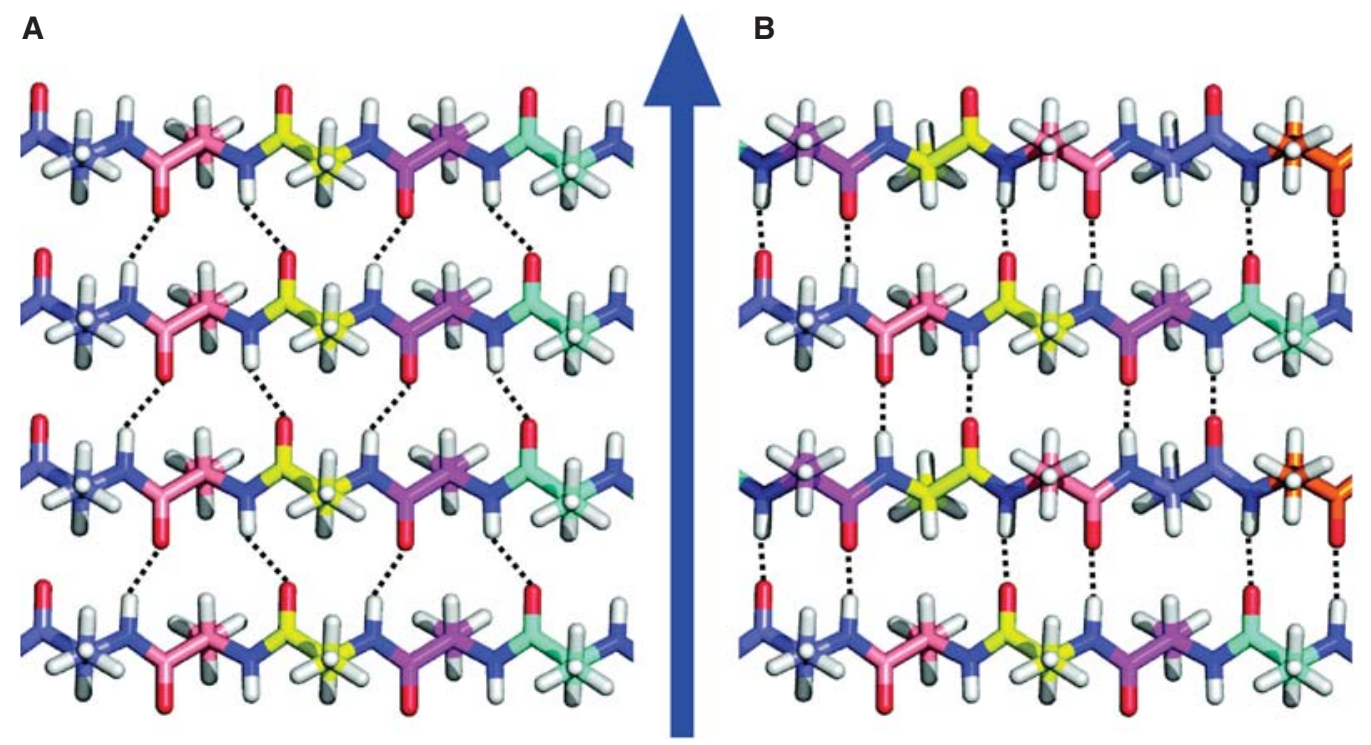

Figure 2. Amyloid fibrils contain $\beta$-sheets that are organized into cross- $\beta$ motifs. ( $A$ ) Idealized representation of an in-register parallel cross- $\beta$ structure, which is formed by identical $\beta$-strand segments from different peptide molecules with intermolecular hydrogen bonds (dotted lines) between residue $\mathrm{k}$ in one $\beta$-strand and residues $\mathrm{k}-1$ and $\mathrm{k}+1$ in an adjacent $\beta$-strand. (B) Idealized representation of an antiparallel cross- $\beta$ structure. The blue arrow represents the fibril growth direction. 
Structure of $A \beta$ Aggregates

A
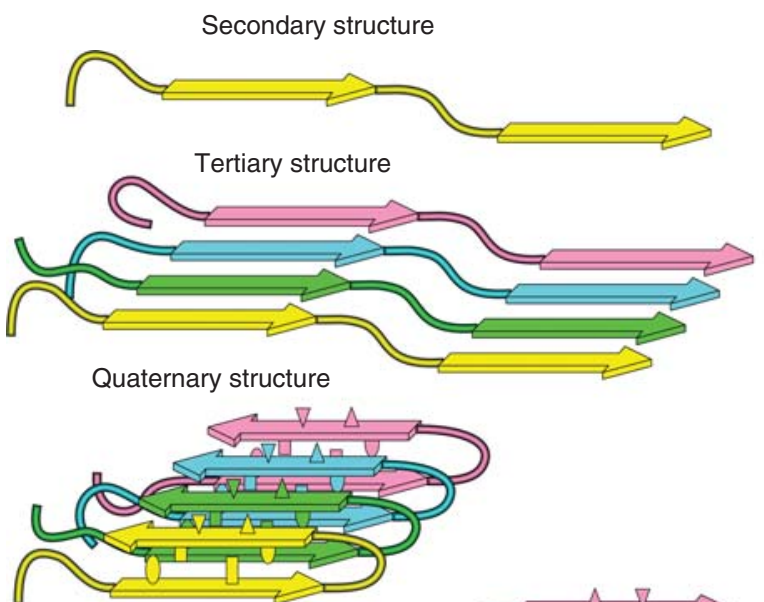

Parallel cross- $\beta$ unit

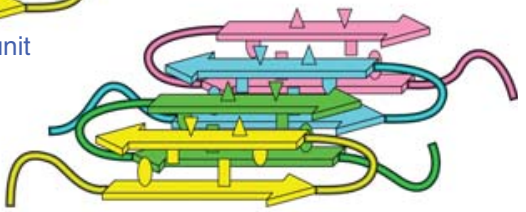

Antiparallel cross- $\beta$ unit

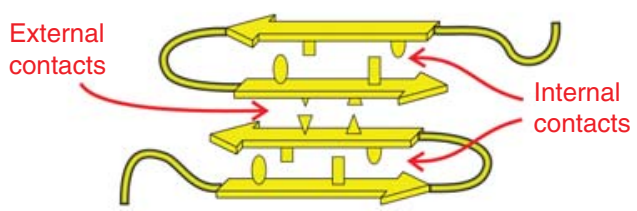

Figure 3. Levels of molecular structure within an amyloid fibril. (A) Secondary structure refers to the identities of $\beta$-strand and non- $\beta$-strand segments (arrows and tubes). Non- $\beta$-strand segments can be either ordered or disordered. $(B)$ Tertiary structure refers to the organization of $\beta$-strand segments into parallel or antiparallel $\beta$-sheets. $(C)$ Quaternary structure refers to the stacking or interactions among $\beta$-sheets, which is mediated by amino acid side chains. A set of molecules that are hydrogen-bonded to one another in $\beta$-sheets constitutes one cross- $\beta$ unit. A fibril structure may contain multiple cross- $\beta$ units. Internal quaternary contacts involve interactions among side chains within one cross- $\beta$ unit (ellipses and rectangles). External quaternary contacts involve interactions among side chains from different cross- $\beta$ units (triangles).

$\beta$-strand-forming segments, or to determine the number of $\beta$-sheet layers within a fibril. Nonetheless, the fact that amyloid fibrils contain cross- $\beta$ structures is a fundamental property that greatly simplifies the development of structural models from ssNMR data (see below).

Methods of ssNMR were first applied to amyloid fibrils by Griffin, Lansbury, and colleagues, who studied fibrils formed by peptides representing residues $34-42$ of $A \beta\left(A \beta_{34-42}\right)$ and residues 20-29 of the islet amyloid polypeptide (Griffiths et al. 1995; Lansbury et al.
1995). Experiments on $A \beta_{34-42}$ fibrils led to a model in which the cross- $\beta$ motif in these fibrils was comprised of antiparallel $\beta$-sheets. These experiments involved preparation of $A \beta_{34-42}$ peptides with ${ }^{13} \mathrm{C}$ labels at specific backbone carbonyl and $\alpha$-carbon sites, and measurements of nuclear magnetic dipole-dipole couplings between the carbonyl and $\alpha$-carbon labels using the "rotational resonance" $\left(\mathrm{R}^{2}\right)$ technique (Raleigh et al. 1988). The strength of magnetic dipole-dipole couplings is inversely proportional to the inverse cube of distances between 
${ }^{13} \mathrm{C}$ labels, allowing $\mathrm{R}^{2}$ data to serve as a strong restraint on molecular structure. The conclusion that $A \beta_{34-42}$ fibrils contain antiparallel $\beta$-sheets followed from the detection of dipole-dipole couplings that were consistent with intermolecular distances $<0.6 \mathrm{~nm}$ between carbonyl and $\alpha$-carbon labels for certain nonsequential residue pairs (Lansbury et al. 1995).

$\mathrm{R}^{2}$ is one example of a class of ssNMR techniques (called "dipolar recoupling” techniques) that are used for quantitative distance measurements in ssNMR studies of biological and nonbiological systems (Raleigh et al. 1988; Gullion and Schaefer 1989; Tycko and Dabbagh 1990; Gregory et al. 1995; Jaroniec et al. 2001; Tycko 2007). Dipolar recoupling techniques generally consist of trains of radio frequency (RF) pulses that are synchronized with rapid rotation of the sample about an axis inclined at the "magic angle," $\theta_{m}=54.7356^{\circ}$, to the external magnetic field of the NMR spectrometer. Magic angle spinning (MAS) is an essential component of most biomolecular ssNMR measurements because MAS produces a dramatic enhancement of spectral resolution and signal-detection sensitivity. Dipolar recoupling techniques restore dipole-dipole couplings that are otherwise averaged out by MAS, allowing internuclear distances to be measured while retaining the resolution and sensitivity advantages of MAS. (In the specific case of $\mathrm{R}^{2}$, no RF pulses are applied, but the MAS rate is adjusted to match the difference in NMR frequencies of the two ${ }^{13}$ C-labeled sites.)

Around 1998, several molecular structural models for fibrils formed by full-length $A \beta$ peptides were proposed (Chaney et al. 1998; Lazo and Downing 1998; George and Howlett 1999; Li et al. 1999; Tjernberg et al. 1999). These models were all qualitatively different from one another, reflecting the fact that no atomiclevel structural restraints for full-length $A \beta$ fibrils were available from experimental measurements. All of these models involved antiparallel $\beta$-sheets, supported by observations from infrared spectroscopy (Hilbich et al. 1991) and the ssNMR data for $A \beta_{34-42}$ fibrils. None of these models has subsequently been found to be correct.
In 1998, Benzinger et al. (1998) reported evidence from ssNMR for parallel $\beta$-sheets in fibrils formed by $A \beta_{10-35}$ (i.e., residues 10-35 of full-length $A \beta$ ), a peptide that had been chosen as a model for full-length $A \beta$ in earlier work (Lee et al. 1995). A series of $A \beta_{10-35}$ samples with ${ }^{13} \mathrm{C}$ labels at single carbonyl sites was prepared. Dipolar recoupling data then indicated intermolecular ${ }^{13} \mathrm{C}-{ }^{13} \mathrm{C}$ distances of $\sim 0.5 \mathrm{~nm}$ for all fibril samples. These data ruled out the possibility of any antiparallel $\beta$-sheet structure and were most consistent with an in-register parallel $\beta$-sheet structure (i.e., one in which identical $\beta$-strand segments from different molecules form $\beta$-sheets, with amino acid residue $\mathrm{k}$ of each molecule being hydrogen-bonded to residues $\mathrm{k}-1$ and $\mathrm{k}+1$ of neighboring molecules, as depicted in Fig. 2A).

Although the results of Benzinger et al. (1998) were initially controversial, subsequent ssNMR data (Antzutkin et al. 2000, 2002; Balbach et al. 2002) provided support for inregister parallel $\beta$-sheets in $A \beta 40, A \beta 42$, and $A \beta_{10-35}$ fibrils. In-register parallel $\beta$-sheets are now known to be the most common type of cross- $\beta$ structure in "mature" (i.e., thermodynamically stable) amyloid fibrils that are formed by polypeptide chains that are more than about 20 residues in length (Margittai and Langen 2008; Tycko and Wickner 2013). Antiparallel $\beta$-sheets have been found in fibrils formed by shorter peptides (Balbach et al. 2000; Petkova et al. 2004; Bu et al. 2007) and in metastable A $\beta$ aggregates (see below).

\section{DEVELOPMENT OF FULL STRUCTURAL MODELS FOR AMYLOID FIBRILS FROM SSNMR DATA: GENERAL CONSIDERATIONS}

As shown schematically in Figure 3, development of a full molecular structural model for an amyloid fibril requires experimental restraints at several structural levels. First, one must obtain restraints on the conformation of individual molecules (i.e., "secondary structure," in the usual terminology of biochemistry and structural biology). In particular, the segments of the amino acid sequence that are conformationally ordered must be distinguished 
from disordered segments, and $\beta$-strand segments must be distinguished from non- $\beta$ strand segments. In ssNMR spectra, ordered segments exhibit sharp, strong ${ }^{13} \mathrm{C}$ and ${ }^{15} \mathrm{~N}$ NMR lines, whereas disordered segments exhibit broader or weaker lines (depending on the hydration level of the sample). Residues in $\beta$-strand segments exhibit characteristic patterns of ${ }^{13} \mathrm{C}$ NMR chemical shifts, with backbone carbonyl and $\alpha$-carbon lines being shifted to lower chemical shift values and $\beta$-carbon lines being shifted to higher chemical shift values relative to "random coil" chemical shifts. (Only glycine $\alpha$-carbon lines do not show this behavior.) Identification of ordered/disordered segments and $\beta$-strand/non- $\beta$-strand segments is performed most efficiently by acquisition of two- or three-dimensional (2D or 3D) ssNMR spectra from fibril samples in which various combinations of residues (or all residues) are uniformly ${ }^{15} \mathrm{~N},{ }^{13} \mathrm{C}$-labeled, allowing the conformations at many sites to be evaluated simultaneously from measurements on a single sample. This strategy was first demonstrated on amyloid fibrils by Balbach et al. (2000). Additional conformational restraints can be obtained from other types of ssNMR measurements (Jaroniec et al. 2002; Antzutkin et al. 2003; Hu et al. 2012), which are especially useful for defining the conformations in non- $\beta$-strand segments and at glycine residues.

Next, one must determine whether the cross- $\beta$ motif is comprised of parallel or antiparallel $\beta$-sheets, as well as the precise intermolecular alignment (i.e., the registry of interstrand hydrogen bonds) within the $\beta$-sheets. In the specific context of amyloid fibrils, this aspect of supramolecular organization can be termed “tertiary structure." As discussed above, dipolar recoupling measurements on samples in which single sites are ${ }^{13} \mathrm{C}$-labeled can provide the necessary restraints on intermolecular distances (Benzinger et al. 1998; Balbach et al. 2002; Tycko 2007). Measurements of ${ }^{15} \mathrm{~N}-{ }^{13} \mathrm{C}$ dipole-dipole couplings on selectively labeled samples are also valuable, especially for characterizing antiparallel $\beta$-sheets (Petkova et al. 2004; Qiang et al. 2012). When multiple residues are uniformly labeled, the intermolecular alignment within antiparallel $\beta$-sheets can also be determined from $2 \mathrm{D}{ }^{13} \mathrm{C}-{ }^{13} \mathrm{C}$ ssNMR spectra obtained with "proton-mediated" transfers of spin polarization between ${ }^{13} \mathrm{C}$ nuclei (Petkova et al. 2004; Qiang et al. 2012). Other ssNMR strategies for characterizing $\beta$-sheet structures have been demonstrated by other research groups (Van Melckebeke et al. 2010; Bayro et al. 2011; Schütz et al. 2014). EPR measurements on spin-labeled peptides and proteins have also produced important information about both the secondary and tertiary structure in fibrils formed by a variety of peptides and proteins (Török et al. 2002; Cobb et al. 2007; Margittai and Langen 2008).

When a polypeptide contains more than one $\beta$-strand segment, $\beta$-sheets formed by different segments can stack against one another. One must then identify the faces of each $\beta$-sheet that form intersheet contacts and the specific amino acid side chains that participate in intersheet interactions. In the specific context of amyloid fibrils, this aspect of supramolecular organization can be termed "quaternary structure." Restraints on intersheet contacts can be obtained from 2D or 3D ssNMR spectra of fibril samples that contain uniformly labeled residues when these spectra are acquired under experimental conditions that lead to long-range interresidue cross-peak signals (Petkova et al. 2006; Paravastu et al. 2008; Van Melckebeke et al. 2010; Qiang et al. 2012; Lu et al. 2013; Schütz et al. 2014). Such cross-peaks result from transfers of nuclear spin polarization between ${ }^{13} \mathrm{C}$, ${ }^{15} \mathrm{~N}$, or ${ }^{1} \mathrm{H}$ sites on side chains of residues that are brought together by intersheet interactions. The polarization transfers are driven by interresidue dipole-dipole couplings and can be observed when, for example, ${ }^{13} \mathrm{C}-{ }^{13} \mathrm{C}$ distances between side chains are up to $\sim 0.8 \mathrm{~nm}$.

The cross- $\beta$ motif formed by one set of molecules that are hydrogen-bonded to one another in $\beta$-sheets can be called one "cross- $\beta$ unit" (CBU). A single fibril can contain two or more CBUs, which are typically arranged in a symmetric manner about the fibril growth axis. The presence of more than one $\mathrm{CBU}$ within $A \beta 40$ and $A \beta 42$ fibrils is indicated by quantitative measurements of the fibril mass per length 
R. Tycko

(MPL) using scanning TEM (STEM) (Goldsbury et al. 2000, 2005; Antzutkin et al. 2002), energy-filtered TEM (Paravastu et al. 2009), or tilted-beam, dark-field TEM (Chen et al. 2009). Given that full-length $A \beta$ peptides have a molecular mass of $4.3 \mathrm{kDa}$ and that the spacing between molecules in an in-register parallel $\beta$-sheet is $0.47 \mathrm{~nm}$, the MPL of one CBU must be $4.3 \mathrm{kDa} / 0.47 \mathrm{~nm}=9.0 \mathrm{kDa} / \mathrm{nm}$. Experimental measurements on $A \beta$ fibrils prepared under various conditions indicate minimum MPL values of $\sim 18$ or $27 \mathrm{kDa} / \mathrm{nm}$ (Goldsbury et al. 2005; Petkova et al. 2005; Chen et al. 2009), consistent with two or three CBUs in the minimal fibril structure, which can be called the "protofilament." Thicker fibrils with higher MPL values can form by self-association of protofilaments, but fibrils containing only one CBU apparently do not exist in isolation.

The existence of multiple CBUs within a protofilament complicates the interpretation of intersheet contacts discussed above because these contacts can be either within one CBU ("internal quaternary contacts") or between different CBUs ("external quaternary contacts"). Assignment of individual long-range inter-residue cross-peaks (or similar data) to internal or external quaternary contacts can only be done reliably after multiple long-range cross-peaks have been observed, so that only one set of assignments is physically possible and internally consistent.

Once experimental restraints on secondary, tertiary, and quaternary structures (as defined above) have been obtained, one can use computational methods to find a final set of structures that are fully consistent with all restraints. The range of variations among these structures can be used as an indication of the precision of the final structural model. Although a larger number of restraints generally leads to greater precision, it should be recognized that accurate structural models for amyloid fibrils do not require a large number of restraints per amino acid residue, as may be the case for globular protein structures. Once the secondary and tertiary structures are determined, fewer than 10 unambiguous, long-range, inter-residue crosspeaks may be sufficient to define the quaternary structure uniquely and accurately (although perhaps not with high precision). This is because a cross- $\beta$ structure requires that all $\beta$-strands in the structure be nearly perpendicular to the fibril growth axis and that all interstrand hydrogen bonds be nearly parallel to the growth axis. In addition, neighboring molecules within one $\mathrm{CBU}$ are related by approximate translational symmetry along the growth axis, and different CBUs are related by approximate rotational or screw symmetry about the growth axis. Symmetry restraints are often imposed to facilitate structural calculations (Lu et al. 2013; Schütz et al. 2014; Sgourakis et al. 2015).

On the other hand, certain aspects of amyloid fibril structures can be nearly impossible to determine from experimental restraints. In particular, when two $\beta$-sheets stack against one another within one CBU, it is well known that amino acid side chains in the interface tend to optimize their packing by interdigitation, leading to displacement or "staggering" of $\beta$-strands in one $\beta$-sheet relative to the other (Buchete et al. 2005; Petkova et al. 2006; Bedrood et al. 2012). The presence of staggering can be inferred from the effects of isotopic dilution on ssNMR measurements of side-chain-sidechain distances or contacts (Petkova et al. 2006; Paravastu et al. 2008). However, the direction of this displacement, which can be toward either end of the fibril, and the amplitude of displacement, which can be more than $0.47 \mathrm{~nm}$, is not readily determined.

\section{MOLECULAR STRUCTURES OF TWO DISTINCT, SELF-PROPAGATING A 340 FIBRIL POLYMORPHS FORMED IN VITRO}

Petkova et al. (2002) used the strategy described above to develop a preliminary model for $A \beta 40$ fibrils, with several characteristic features: (1) the $A \beta 40$ conformation includes a disordered $\mathrm{N}$-terminal segment (residues 1-9), two $\beta$ strand segments (residues 10-22 and 30-40), and an intervening bend or loop (residues $23-29$ ); (2) the two $\beta$-strand segments form separate in-register parallel $\beta$-sheets, so that the $\mathrm{CBU}$ is a double-layered parallel $\beta$-sheet structure, with internal quaternary contacts involv- 
ing favorable hydrophobic interactions among side chains of the two $\beta$-strands; (3) oppositely charged side chains of D23 and K28 form salt bridges within the core of the CBU; and (4) the protofilament consists of two CBUs, with external quaternary contacts involving hydrophobic residues of the C-terminal $\beta$-strand as well as side-chain interdigitation, as in "steric zippers" identified by Eisenberg and colleagues (Nelson et al. 2005; Sawaya et al. 2007).

This preliminary model was a significant advance over earlier modeling attempts in that it was consistent with a substantial set of experimental observations, including the existing data from ssNMR (Balbach et al. 2002; Petkova et al. 2002), electron microscopy (Antzutkin et al. 2002), EPR (Török et al. 2002), hydrogen/deuterium exchange (Kheterpal et al. 2000), and limited proteolysis (Kheterpal et al. 2001). Important features of this model have been retained in subsequent structural models, including the overall conformation of $\mathrm{A} \beta 40$ monomers, the identities of exposed and buried segments, the in-register parallel $\beta$-sheet organization, the presence of D23-K28 salt bridges, the existence of two CBUs within the protofilament, and the hydrophobic fibril core that results from these structural features.

However, it became clear that a single $A \beta 40$ fibril structure could not explain all observations, especially that ${ }^{13} \mathrm{C}$ NMR chemical shifts for individual sites varied from one fibril sample to another (Petkova et al. 2002), that MPL values of $18 \mathrm{kDa} / \mathrm{nm}$ and $27 \mathrm{kDa} / \mathrm{nm}$ were observed in different samples (Goldsbury et al. 2005), and that ssNMR data restraining the conformation in residues 23-29 could not be fit well by a single conformation (Antzutkin et al. 2003). Then, Petkova et al. (2005) showed that the molecular structure of $A \beta 40$ fibrils is reproducibly dependent on the precise details of growth conditions. Depending on the presence or absence of gentle agitation of the $\mathrm{A} \beta 40$ solution during fibril growth, with all other conditions being equal, fibrils with two distinct morphologies in TEM images, distinct sets of NMR chemical shifts, and distinct MPL values could be prepared. Moreover, once a batch of "parent" fibrils with a particular structure was prepared de novo, subsequent samples of "daughter" and "granddaughter" fibrils, with the same structures as their parents, could be prepared by seeded fibril growth (Petkova et al. 2005). Thus, the molecular structure in $A \beta$ fibrils is not determined uniquely by amino acid sequence.

Once the phenomenon of self-propagating molecular-level polymorphism in A $\beta$ fibrils was established, protocols for preparing relatively homogeneous samples were developed (Petkova et al. 2006; Paravastu et al. 2008). Structural models for the two A $\beta 40$ fibril polymorphs shown in Figure 1A and B were then developed from ssNMR data. As shown in Figure 4, the two polymorphs possess quite similar secondary structures, identical tertiary structures, similar internal quaternary contacts, and the same A $\beta 40$ segments exposed on the protofilament surface. The most striking difference is in their symmetry. Fibrils grown with gentle agitation contain protofilaments comprised of two CBUs, with approximate twofold rotational symmetry about the fibril growth axis (Fig. $4 \mathrm{~A}$ ). These protofilaments tend to self-associate to form "striated ribbons" in negatively stained TEM images (Fig. 1A). Fibrils grown under quiescent conditions contain protofilaments with three CBUs and approximate threefold rotation symmetry (Fig. 4B). The fibrils are less prone to self-association, so that negatively stained TEM images typically show individual protofilaments, with a gradual twist along their length (Fig. 1B). The D23-K28 salt bridges discussed above are present in the twofold symmetric fibrils, but not in the threefold symmetric fibrils, as revealed by differences in ${ }^{15} \mathrm{~N}-{ }^{13} \mathrm{C}$ dipoledipole couplings between D23 and K28 side chains (Paravastu et al. 2008). This difference is one manifestation of significant conformational differences in residues 23-29.

Atomic coordinates for twofold and threefold symmetric $A \beta 40$ fibrils formed in vitro can be found in the Research Collaboratory for Structural Bioinformatics (RCSB) Protein Data Bank (PDB codes 2LMN and 2LMO for twofold symmetric fibrils; PDB codes 2LMP and 2LMQ for threefold symmetric fibrils). For each polymorph, the two sets of coordinates 
R. Tycko

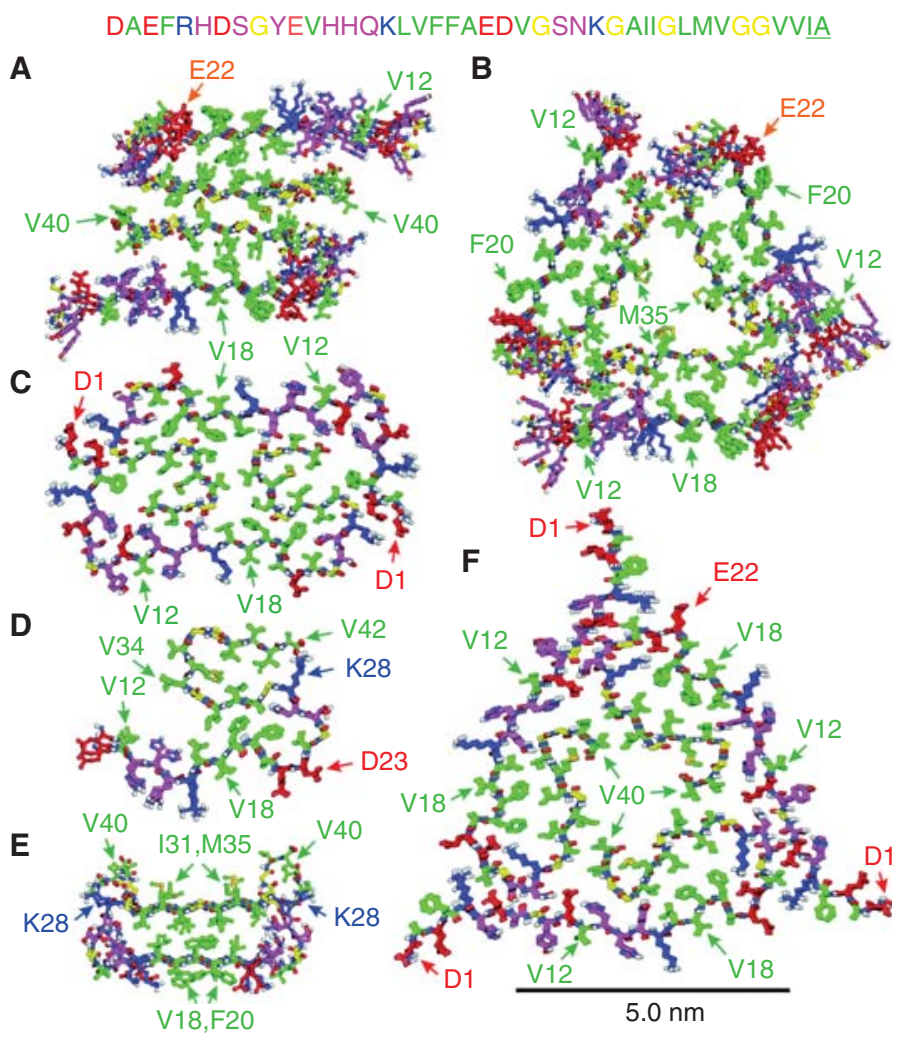

Figure 4. Molecular structures of $A \beta$ aggregates developed from ssNMR data. ( $A$ ) Twofold symmetric A $\beta 40$ fibril with the morphology in Figure 1A from Protein Data Bank (PDB) file 2LMN. (B) Threefold symmetric A $\beta 40$ fibril with the morphology in Figure 1B from PDB file 2LMP. (C) E22 $\Delta-\mathrm{A} \beta 40$ fibril from PDB file 2MVX. $(D)$ A 342 fibril from PDB file 2MXU. (E) D23N-A 340 protofibril from PDB file 2LNQ. (F) Brain-derived A $\beta 40$ fibril with the morphology in Figure 1C from PDB file 2M4J. All models are viewed in cross section, with the fibril or protofibril growth axis perpendicular to the page. Three or four molecular repeats along the growth axis are shown in each case. Carbon atoms of hydrophobic, negatively charged, positively charged, and glycine residues are green, red, blue, and yellow, respectively. Carbon atoms of other residues are magenta. In $C, D$, and $F$ (but not $A, B$, and $E$ ), conformational and translational symmetry restraints were imposed during structure calculations. The amino acid sequences of wild-type $A \beta 40$ and $A \beta 42$ (including the two underlined C-terminal residues) are shown at the top.

involve different directions of staggering. As discussed above, isotopic dilution experiments indicate that internal quaternary contacts in both polymorphs are staggered, but the direction cannot be determined from existing data.

\section{OTHER STRUCTURAL MODELS FOR IN VITRO A $\beta$ FIBRILS DEVELOPED FROM sSNMR DATA}

An additional twofold symmetric structural model for $\mathrm{A} \beta 40$ fibrils was subsequently devel- oped from ssNMR data by Bertini et al. (2011). The details of internal and external quaternary contacts are different in this model compared with the model in Figure 4A, although the identities of amino acid side chains that are involved in these contacts are the same. Residues 1-9 are not fully disordered in fibrils studied by Bertini et al. (2011). Significant differences in growth conditions and the presence of a nonnative methionine residue at the $N$ terminus in $\mathrm{A} \beta 40$ samples prepared by Bertini et al. (2011) most likely account for the structural differences. 
A threefold symmetric structural model for fibrils formed by the Asp23Asn "Iowa" mutant of A 340 (D23N-A 340$)$ (Grabowski et al. 2001) has been reported by Sgourakis et al. (2015). This model is very similar to the model for wild-type Aß40 fibrils in Figure 4B. Differences include the presence of external quaternary contacts between V40 and K28 in the D23NA $\beta 40$ fibrils and conformational differences in residues 23-29.

Figure 4C shows a twofold symmetric structural model for fibrils formed by the Glu22-deletion "Osaka" mutant of A $\beta 40(\mathrm{E} 22 \Delta-\mathrm{A} \beta 40)$ (Tomiyama et al. 2008), which was developed by Schütz et al. (2014). The entire E22 $\Delta-A \beta 40$ sequence was found to be structurally ordered, as indicated by the detection of sharp, strong NMR signals from all residues. Significant differences in secondary and quaternary structures were found, compared with the twofold symmetric, wild-type A $\beta 40$ structure in Figure $4 \mathrm{~A}$, and D23-K28 salt bridges were found to be absent. The in-register parallel $\beta$-sheet structure formed by residues $30-40$ is divided into three separate sections by turn-like conformations at glycine residues 33 and 37 .

Figure 4D shows a partial structural model for fibrils formed in vitro by $A \beta 42$, developed by Xiao et al. (2015). In this case, residues $12-15$, $17-19,26-28,30-33$, and 38-40 form separate parallel $\beta$-sheets, with salt bridges between K28 and $\mathrm{A} 42$. This is a partial model because only one CBU is included, although MPL data for A 342 fibrils indicate two or more CBUs (Antzutkin et al. 2002). The structural differences between $A \beta 42$ and $A \beta 40$ fibrils identified by Xiao et al. (2015) help explain the fact that $A \beta 42$ fibril fragments do not act as efficient seeds for the growth of $\mathrm{A} \beta 40$ fibrils, at least for polymorphs that have been examined in vitro (Lu et al. 2013; Cukalevski et al. 2015). The absence of efficient cross-seeding suggests that $A \beta 40$ fibrils and A $\beta 42$ fibrils may develop and propagate independently of one another in brain tissue.

\section{MOLECULAR STRUCTURES OF TRANSIENT AND METASTABLE A $\beta$ AGGREGATES}

In studies of $A \beta$ aggregation in vitro, TEM and atomic-force microscope images commonly show a variety of aggregated states that are not true mature fibrils. These nonfibrillar states often appear before mature fibrils and may persist for hours or days but eventually disappear as self-assembly proceeds to its thermodynamic end point. Hence, they are considered to be intermediate stages in $A \beta$ aggregation. Intermediates include $A \beta$ oligomers with roughly spherical appearances and variable sizes and A $\beta$ protofibrils, which are worm-like in appearance, with greater curvature and shorter lengths than mature fibrils. Nonfibrillar species are of great interest in the research community because of experimental evidence that they may be important neurotoxic species in $\mathrm{AD}$ (Lambert et al. 1998; Walsh et al. 2002; Kayed et al. 2003; Williams et al. 2005; Lesne et al. 2006, 2013; Glabe 2008; Tomic et al. 2009; LasagnaReeves et al. 2011; Liu et al. 2015).

A variety of oligomeric and protofibrillar states have been partially characterized by ssNMR (Ahmed et al. 2010; Scheidt et al. 2011, 2012; Lopez del Amo et al. 2012; Tay et al. 2013; Lendel et al. 2014; Sarkar et al. 2014; Huang et al. 2015; Parthasarathy et al. 2015; Potapov et al. 2015). The main finding, originally reported by Ishii and coworkers (Chimon and Ishii 2005; Chimon et al. 2007), is that the $\mathrm{A} \beta$ conformation in nonfibrillar intermediates is remarkably similar to the conformation in fibrils. Most data on supramolecular structure indicate that in-register parallel $\beta$-sheets are not present in nonfibrillar intermediates and that the predominant intermolecular alignment may be antiparallel (Tay et al. 2013; Huang et al. 2015; Potapov et al. 2015). Ishii and coworkers have reported dipolar recoupling data that support parallel intermolecular alignment in large, spherical $A \beta 40$ intermediates (Chimon et al. 2007; Parthasarathy et al. 2015).

To date, only one detailed molecular structural model for an intermediate has been reported, namely, a model for protofibrils formed by D23N-A 340 (Qiang et al. 2012). As shown in Figure 4E, D23N-A 340 protofibrils contain a molecular conformation that is similar to the conformation in A $\beta 40$ fibrils, with residues 1622 and $30-34$ forming $\beta$-strands that interact through hydrophobic side-chain-side-chain 
contacts. However, the supramolecular structure is qualitatively different, with an alternating, antiparallel alignment of D23-A $\beta 40$ molecules that creates a double-layered antiparallel CBU. MPL data indicate that the protofibrils contain only one CBU. The model for D23N$\mathrm{A} \beta 40$ protofibrils in Figure 4E (PDB code 2LNQ) is supported by NMR chemical shifts, long-range cross-peaks, intermolecular ${ }^{13} \mathrm{C}-{ }^{13} \mathrm{C}$ and ${ }^{15} \mathrm{~N}-{ }^{13} \mathrm{C}$ dipole-dipole couplings, and multiple proton-mediated $2 \mathrm{D}{ }^{13} \mathrm{C}-{ }^{13} \mathrm{C}$ spectra (Qiang et al. 2012).

D23N-A 340 protofibrils eventually convert to fibrils with threefold symmetry and inregister parallel $\beta$-sheets (Tycko et al. 2009; Qiang et al. 2011) but can persist for many weeks. Metastability of protofibrils can be attributed to the favorable hydrophobic interactions in the protofibril core and to their qualitatively different supramolecular structure. Spontaneous internal conversion of protofibrils to fibrils would require a dramatic rearrangement of all intermolecular hydrogen bonds and would be additionally hindered by numerous steric clashes. Conversion to fibrils can only occur through gradual shrinkage and dissolution of the metastable protofibrils and gradual elongation of the more thermodynamically stable fibrils, as discussed elsewhere (Qiang et al. 2013; Tycko 2014). Because direct, internal conversion of protofibrils to fibrils cannot occur, protofibrils are "off-pathway" intermediates in the $A \beta$ self-assembly process. It appears likely that most intermediates that have been examined by in vitro experiments are also off-pathway, with the possible exception of the oligomers studied by Ishii and colleagues (Chimon et al. 2007; Parthasarathy et al. 2015).

\section{AGGREGATED A $\beta$ IN BRAIN TISSUE}

In light of the molecular-level polymorphism of $\mathrm{A} \beta$ fibrils that has been established by in vitro studies, as well as the observation of multiple self-assembly intermediates, it is important to ask which $A \beta$ structures actually develop in brain tissue. Direct structural characterization of aggregated $A \beta$ in brain tissue by ssNMR is not possible because ssNMR measurements re- quire milligram-scale quantities of isotopically labeled material. However, fibril structures in brain tissue can be amplified and labeled by seeded fibril growth, using amyloid-containing brain extract as the source of seeds and labeled $\mathrm{A} \beta$ (either synthetic or recombinant) as the source of monomers that add to the brain-derived seeds (Paravastu et al. 2009). Using this approach, Lu et al. (2013) investigated A $\beta 40$ fibrils derived from brain tissue of two AD patients. Surprisingly, ssNMR spectra of brainderived fibrils indicated highly homogenous structures, with the same predominant structures in different regions of the cerebral cortex from each patient. However, spectra of $A \beta 40$ fibrils from patient 1 were dramatically different from spectra of $\mathrm{A} \beta 40$ fibrils from patient 2, indicating significant differences in secondary structure. Moreover, the two patients had different clinical histories, raising the possibility that differences in fibril structure may correlate with differences in disease development.

A complete structural model for fibrils derived from patient 1, shown in Figure 4F, was developed from a large set of ssNMR data (PDB code 2M4J) (Lu et al. 2013). These fibrils have threefold symmetry and share many aspects of secondary, tertiary, and quaternary structure with $A \beta 40$ fibrils prepared in vitro. Significant differences from the in vitro threefold symmetric $\mathrm{A} \beta 40$ fibrils studied by Paravastu et al. (2008) (Fig. 4B) include the presence of D23-K28 salt bridges, structurally ordered $\mathrm{N}$-terminal segments, and breaks in the C-terminal $\beta$-strand at glycine residues 33 and 37 . Some of these features are also present in ssNMR-based structural models for fibrils formed in vitro by E22 $\Delta-$ $\mathrm{A} \beta 40$ and $\mathrm{A} \beta 42$ (Figs. 4C,D). Thus, $\mathrm{A} \beta$ fibrils that develop in brain tissue and can be amplified with the protocols of Lu et al. (2013) are qualitatively similar to fibrils prepared in vitro but differ in specific details. Although a structural model for fibrils derived from patient 2 was not developed by Lu et al. (2013), ssNMR spectra and MPL data indicate threefold symmetry but with differences in internal quaternary contacts and in the conformation in residues $28-32$.

Structural variations discussed above may provide a basis for the development of com- 
pounds for diagnostic imaging (Klunk et al. 2004; Wong et al. 2010) that distinguish among $\mathrm{A} \beta$ fibril polymorphs in living patients. If significant correlations between variations in fibril structure and variations in disease development (e.g., progression from mild cognitive impairment to $\mathrm{AD}$ ) are established by future studies, such imaging compounds may be valuable in clinical practice. Similarly, if certain fibril polymorphs are shown to have higher pathogenicity, specific structural differences among polymorphs may provide a basis for the development of compounds that direct $A \beta$ aggregation toward relatively innocuous structures.

\section{CONCLUDING REMARKS}

As described above, we now have a good understanding of molecular structures and structural variations within $A \beta$ fibrils, which was largely absent 15 years ago. Although not all possible structures (including all disease-associated mutants, $A \beta$ peptide lengths, and fibril polymorphs) have been characterized, it now seems most important to focus on those that develop in brain tissue. A critical question for which the current answer appears to be "possibly yes" (Heilbronner et al. 2013; Lu et al. 2013; Stöhr et al. 2014; Watts et al. 2014; Cohen et al. 2015) is whether structural variations are clinically relevant. Further experiments are needed using ssNMR measurements on brain-seeded fibrils as described above or perhaps using techniques that provide less detailed structural information but require less material (Bergh et al. 2015). In addition, further clarification of molecular structures within nonfibrillar $A \beta$ aggregates is an important goal for future experiments. Because nonfibrillar aggregates are apparently not amenable to amplification and isotopic labeling by seeded growth, structural studies of nonfibrillar aggregates from brain tissue may depend on methods other than ssNMR.

\section{ACKNOWLEDGMENTS}

Research on A $\beta$ structures in Dr. Tycko's laboratory is supported by the Intramural Research Program of the National Institute of Diabetes and Digestive and Kidney Diseases, a component of the National Institutes of Health.

\section{REFERENCES}

Ahmed M, Davis J, Aucoin D, Sato T, Ahuja S, Aimoto S, Elliott JI, Van Nostrand WE, Smith SO. 2010. Structural conversion of neurotoxic amyloid- $\beta_{1-42}$ oligomers to fibrils. Nat Struct Mol Biol 17: 561-567.

Antzutkin ON, Balbach JJ, Leapman RD, Rizzo NW, Reed J, Tycko R. 2000. Multiple quantum solid state NMR indicates a parallel, not antiparallel, organization of $\beta$-sheets in Alzheimer's $\beta$-amyloid fibrils. Proc Natl Acad Sci 97: 13045-13050.

Antzutkin ON, Leapman RD, Balbach JJ, Tycko R. 2002. Supramolecular structural constraints on Alzheimer's $\beta$-amyloid fibrils from electron microscopy and solid state nuclear magnetic resonance. Biochemistry 41: 15436-15450.

Antzutkin ON, Balbach JJ, Tycko R. 2003. Site-specific identification of non- $\beta$-strand conformations in Alzheimer's $\beta$-amyloid fibrils by solid state NMR. Biophys J 84: 33263335 .

Arai H, Lee VM, Messinger ML, Greenberg BD, Lowery DE, Trojanowski JQ. 1991. Expression patterns of $\beta$-amyloid precursor protein ( $\beta$-APP) in neural and nonneural human tissues from Alzheimer's-disease and control subjects. Ann Neurol 30: 686-693.

Astbury WT, Beighton E, Parker KD. 1959. The cross- $\beta$ configuration in supercontracted proteins. Biochim Biophys Acta 35: 17-25.

Balbach JJ, Ishii Y, Antzutkin ON, Leapman RD, Rizzo NW, Dyda F, Reed J, Tycko R. 2000. Amyloid fibril formation by $A \beta_{16-22}$, a seven-residue fragment of the Alzheimer's $\beta$-amyloid peptide, and structural characterization by solid state NMR. Biochemistry 39: 13748-13759.

Balbach JJ, Petkova AT, Oyler NA, Antzutkin ON, Gordon DJ, Meredith SC, Tycko R. 2002. Supramolecular structure in full-length Alzheimer's $\beta$-amyloid fibrils: Evidence for a parallel $\beta$-sheet organization from solid state nuclear magnetic resonance. Biophys J 83: 1205-1216.

Bayro MJ, Debelouchina GT, Eddy MT, Birkett NR, MacPhee CE, Rosay M, Maas WE, Dobson CM, Griffin RG. 2011. Intermolecular structure determination of amyloid fibrils with magic-angle spinning and dynamic nuclear polarization NMR. J Am Chem Soc 133: 1396713974.

Bedrood S, Li YY, Isas JM, Hegde BG, Baxa U, Haworth IS, Langen R. 2012. Fibril structure of human islet amyloid polypeptide. J Biol Chem 287: 5235-5241.

Benzinger TL, Gregory DM, Burkoth TS, Miller-Auer H, Lynn DG, Botto RE, Meredith SC. 1998. Propagating structure of Alzheimer's $\beta$-amyloid $(10-35)$ is parallel $\beta$ sheet with residues in exact register. Proc Natl Acad Sci 95: 13407-13412.

Bergh J, Zetterström P, Andersen PM, Brännström T, Graffmo KS, Jonsson PA, Lang LS, Danielsson J, Oliveberg M, Marklund SL. 2015. Structural and kinetic analysis of protein-aggregate strains in vivo using binary epitope mapping. Proc Natl Acad Sci 112: 4489-4494. 
R. Tycko

Bertini I, Gonnelli L, Luchinat C, Mao JF, Nesi A. 2011. A new structural model of $A \beta_{40}$ fibrils. J Am Chem Soc 133: 16013-16022.

Brännström K, Öhman A, Lindhagen-Persson $\mathrm{M}$, Olofsson A. 2013. $\mathrm{Ca}^{2+}$ enhances $A \beta$ polymerization rate and fibrillar stability in a dynamic manner. Biochem $J$ 450: 189-197.

Bu ZM, Shi Y, Callaway DJE, Tycko R. 2007. Molecular alignment within $\beta$-sheets in $A \beta_{14-23}$ fibrils: Solid state NMR experiments and theoretical predictions. Biophys $J$ 92: 594-602.

Buchete NV, Tycko R, Hummer G. 2005. Molecular dynamics simulations of Alzheimer's $\beta$-amyloid protofilaments. J Mol Biol 353: 804-821.

Chaney MO, Webster SD, Kuo YM, Roher AE. 1998. Molecular modeling of the amyloid $\beta$ 1-42 peptide from Alzheimer's disease. Protein Eng 11: 761-767.

Chen B, Thurber KR, Shewmaker F, Wickner RB, Tycko R. 2009. Measurement of amyloid fibril mass-per-length by tilted-beam transmission electron microscopy. Proc Natl Acad Sci 106: 14339-14344

Chimon S, Ishii Y. 2005. Capturing intermediate structures of Alzheimer's $\beta$-amyloid, $A \beta(1-40)$, by solid state NMR spectroscopy. J Am Chem Soc 127: 13472-13473.

Chimon S, Shaibat MA, Jones CR, Calero DC, Aizezi B, Ishii Y. 2007. Evidence of fibril-like $\beta$-sheet structures in a neurotoxic amyloid intermediate of Alzheimer's $\beta$-amyloid. Nat Struct Mol Biol 14: 1157-1164.

Cobb NJ, Sonnichsen FD, McHaourab H, Surewicz WK. 2007. Molecular architecture of human prion protein amyloid: A parallel, in-register $\beta$-structure. Proc Nat Acad Sci 104: 18946-18951.

Cohen M, Kim C, Haldiman T, Elhag M, Tatsuoka C, Zhang SL, Haines J, Lerner A, Safar J. 2015. Distinct strains of amyloid $\beta$ prions implicated in rapidly progressive Alzheimer disease. Prion 9: S76-S77.

Cukalevski R, Yang XT, Meisl G, Weininger U, Bernfur K, Frohm B, Knowles TPJ, Linse S. 2015. The $A \beta 40$ and A 342 peptides self-assemble into separate homomolecular fibrils in binary mixtures but cross-react during primary nucleation. Chem Sci 6: 4215-4233.

Deshpande A, Mina E, Glabe C, Busciglio J. 2006. Different conformations of amyloid $\beta$ induce neurotoxicity by distinct mechanisms in human cortical neurons. J Neurosci 26: 6011-6018.

Eanes ED, Glenner GG. 1968. X-ray diffraction studies on amyloid filaments. J Histochem Cytochem 16: 673-677.

George AR, Howlett DR. 1999. Computationally derived structural models of the $\beta$-amyloid found in Alzheimer's disease plaques and the interaction with possible aggregation inhibitors. Biopolymers 50: 733-741.

Glabe CG. 2008. Structural classification of toxic amyloid oligomers. J Biol Chem 283: 29639-29643.

Goldsbury CS, Wirtz S, Müller SA, Sunderji S, Wicki P, Aebi U, Frey P. 2000. Studies on the in vitro assembly of $A \beta 1-$ 40: Implications for the search for $A \beta$ fibril formation inhibitors. J Struct Biol 130: 217-231.

Goldsbury C, Frey P, Olivieri V, Aebi U, Müller SA. 2005. Multiple assembly pathways underlie amyloid- $\beta$ fibril polymorphisms. J Mol Biol 352: 282-298.
Grabowski TJ, Cho HS, Vonsattel JPG, Rebeck GW, Greenberg SM. 2001. Novel amyloid precursor protein mutation in an Iowa family with dementia and severe cerebral amyloid angiopathy. Ann Neurol 49: 697-705.

Gravina SA, Ho LB, Eckman CB, Long KE, Otvos L, Younkin LH, Suzuki N, Younkin SG. 1995. Amyloid- $\beta$ protein $(A \beta)$ in Alzheimer's-disease brain: Biochemical and immunocytochemical analysis with antibodies specific for forms ending at $A \beta-40$ or $A \beta-42(43)$. J Biol Chem 270: 7013-7016.

Gregory DM, Mitchell DJ, Stringer JA, Kiihne S, Shiels JC, Callahan J, Mehta MA, Drobny GP. 1995. Windowless dipolar recoupling: The detection of weak dipolar couplings between spin $1 / 2$ nuclei with large chemical shift anisotropies. Chem Phys Lett 246: 654-663.

Griffiths JM, Ashburn TT, Auger M, Costa PR, Griffin RG, Lansbury PT. 1995. Rotational resonance solid state NMR elucidates a structural model of pancreatic amyloid. J Am Chem Soc 117: 3539-3546.

Gullion T, Schaefer J. 1989. Rotational-echo double-resonance NMR. J Magn Reson 81: 196-200.

Haass C, Selkoe DJ. 1993. Cellular processing of $\beta$-amyloid precursor protein and the genesis of amyloid $\beta$-peptide. Cell 75: 1039-1042.

Hardy J. 2006. Has the amyloid cascade hypothesis for Alzheimer's disease been proved? Curr Alzheimer Res 3: $71-73$.

Heilbronner G, Eisele YS, Langer F, Kaeser SA, Novotny R, Nagarathinam A, Aslund A, Hammarström P, Nilsson KPR, Jucker M. 2013. Seeded strain-like transmission of $\beta$-amyloid morphotypes in APP transgenic mice. EMBO Rep 14: 1017-1022.

Hilbich C, Kisters-Woike B, Reed J, Masters CL, Beyreuther K. 1991. Aggregation and secondary structure of synthetic amyloid $\beta A 4$ peptides of Alzheimer's disease. J Mol Biol 218: 149-163.

Hu KN, Qiang W, Bermejo GA, Schwieters CD, Tycko R. 2012. Restraints on backbone conformations in solid state NMR studies of uniformly labeled proteins from quantitative amide ${ }^{15} \mathrm{~N}-{ }^{15} \mathrm{~N}$ and carbonyl ${ }^{13} \mathrm{C}-{ }^{13} \mathrm{C}$ dipolar recoupling data. J Magn Reson 218: 115-127.

Huang DT, Zimmerman MI, Martin PK, Nix AJ, Rosenberry TL, Paravastu AK. 2015. Antiparallel $\beta$-sheet structure within the C-terminal region of 42-residue Alzheimer's amyloid- $\beta$ peptides when they form $150-\mathrm{kDa}$ oligomers. J Mol Biol 427: 2319-2328.

Jaroniec CP, Tounge BA, Herzfeld J, Griffin RG. 2001. Frequency selective heteronuclear dipolar recoupling in rotating solids: Accurate ${ }^{13} \mathrm{C}-{ }^{15} \mathrm{~N}$ distance measurements in uniformly ${ }^{13} \mathrm{C},{ }^{15} \mathrm{~N}$-labeled peptides. J Am Chem Soc 123: $3507-3519$.

Jaroniec CP, Filip C, Griffin RG. 2002. 3D TEDOR NMR experiments for the simultaneous measurement of multiple carbon-nitrogen distances in uniformly ${ }^{13} \mathrm{C},{ }^{15} \mathrm{~N}$ labeled solids. J Am Chem Soc 124: 10728-10742.

Jaroniec CP, MacPhee CE, Bajaj VS, McMahon MT, Dobson CM, Griffin RG. 2004. High-resolution molecular structure of a peptide in an amyloid fibril determined by magic angle spinning NMR spectroscopy. Proc Natl Acad Sci 101: $711-716$

Jiménez JL, Guijarro JL, Orlova E, Zurdo J, Dobson CM, Sunde M, Saibil HR. 1999. Cryo-electron microscopy 
structure of an SH3 amyloid fibril and model of the molecular packing. Embo J 18: 815-821.

Kayed R, Head E, Thompson JL, McIntire TM, Milton SC, Cotman CW, Glabe CG. 2003. Common structure of soluble amyloid oligomers implies common mechanism of pathogenesis. Science 300: 486-489.

Kheterpal I, Wetzel R. 2006. Hydrogen/deuterium exchange mass spectrometry-A window into amyloid structure. Acc Chem Res 39: 584-593.

Kheterpal I, Zhou S, Cook KD, Wetzel R. 2000. A $\beta$ amyloid fibrils possess a core structure highly resistant to hydrogen exchange. Proc Natl Acad Sci 97: 13597-13601.

Kheterpal I, Williams A, Murphy C, Bledsoe B, Wetzel R. 2001. Structural features of the $A \beta$ amyloid fibril elucidated by limited proteolysis. Biochemistry 40: $11757-$ 11767.

Klinger AL, Kiselar J, Ilchenko S, Komatsu H, Chance MR, Axelsen PH. 2014. A synchrotron-based hydroxyl radical footprinting analysis of amyloid fibrils and prefibrillar intermediates with residue-specific resolution. Biochemistry 53: 7724-7734.

Klunk WE, Engler H, Nordberg A, Wang YM, Blomqvist G, Holt DP, Bergstrom M, Savitcheva I, Huang GF, Estrada S, et al. 2004. Imaging brain amyloid in Alzheimer's disease with Pittsburgh compound-B. Ann Neurol 55: 306-319.

Kodali R, Williams AD, Chemuru S, Wetzel R. 2010. A $\beta$ (140) forms five distinct amyloid structures whose $\beta$-sheet contents and fibril stabilities are correlated. J Mol Biol 401: 503-517.

Kuo YM, Emmerling MR, Vigo-Pelfrey C, Kasunic TC, Kirkpatrick JB, Murdoch GH, Ball MJ, Roher AE. 1996. Water-soluble $\mathrm{A} \beta(\mathrm{N}-40, \mathrm{~N}-42)$ oligomers in normal and Alzheimer disease brains. J Biol Chem 271: 4077-4081.

Ladiwala ARA, Litt J, Kane RS, Aucoin DS, Smith SO, Ranjan S, Davis J, Van Nostrand WE, Tessier PM. 2012. Conformational differences between two amyloid $\beta$ oligomers of similar size and dissimilar toxicity. J Biol Chem 287: 24765-24773.

Laganowsky A, Liu C, Sawaya MR, Whitelegge JP, Park J, Zhao ML, Pensalfini A, Soriaga AB, Landau M, Teng PK, et al. 2012. Atomic view of a toxic amyloid small oligomer. Science 335: 1228-1231.

Lambert MP, Barlow AK, Chromy BA, Edwards C, Freed R, Liosatos M, Morgan TE, Rozovsky I, Trommer B, Viola KL, et al. 1998. Diffusible, nonfibrillar ligands derived from $A \beta_{1-42}$ are potent central nervous system neurotoxins. Proc Natl Acad Sci 95: 6448-6453.

Lansbury PT, Costa PR, Griffiths JM, Simon EJ, Auger M, Halverson KJ, Kocisko DA, Hendsch ZS, Ashburn TT, Spencer RGS, et al. 1995. Structural model for the $\beta$ amyloid fibril based on interstrand alignment of an antiparallel-sheet comprising a C-terminal peptide. Nat Struct Biol 2: 990-998.

Lasagna-Reeves CA, Glabe CG, Kayed R. 2011. Amyloid- $\beta$ annular protofibrils evade fibrillar fate in Alzheimer disease brain. J Biol Chem 286: 22122-22130.

Lazo ND, Downing DT. 1998. Amyloid fibrils may be assembled from $\beta$-helical protofibrils. Biochemistry 37: 1731-1735.

Lee JP, Stimson ER, Ghilardi JR, Mantyh PW, Lu YA, Felix AM, Llanos W, Behbin A, Cummings M, Van Criekinge
M, et al. 1995. ${ }^{1} \mathrm{H}$ NMR of $\mathrm{A} \beta$ amyloid peptide congeners in water solution. Conformational changes correlate with plaque competence. Biochemistry 34: 5191-5200.

Lendel C, Bjerring M, Dubnovitsky A, Kelly RT, Filippov A, Antzutkin ON, Nielsen NC, Härd T. 2014. A hexameric peptide barrel as building block of amyloid- $\beta$ protofibrils. Angew Chem Int Ed Engl 53: 12756-12760.

Lesne S, Koh MT, Kotilinek L, Kayed R, Glabe CG, Yang A, Gallagher M, Ashe KH. 2006. A specific amyloid- $\beta$ protein assembly in the brain impairs memory. Nature 440: 352-357.

Lesne SE, Sherman MA, Grant M, Kuskowski M, Schneider JA, Bennett DA, Ashe KH. 2013. Brain amyloid- $\beta$ oligomers in ageing and Alzheimer's disease. Brain 136: $1383-$ 1398.

Li LP, Darden TA, Bartolotti L, Kominos D, Pedersen LG. 1999. An atomic model for the pleated $\beta$-sheet structure of A $\beta$ amyloid protofilaments. Biophys J 76: 2871-2878.

Liu P, Reed MN, Kotilinek LA, Grant MKO, Forster CL, Qiang W, Shapiro SL, Reichl JH, Chiang ACA, Jankowsky JL, et al. 2015. Quaternary structure defines a large class of amyloid- $\beta$ oligomers neutralized by sequestration. Cell Rep 11: 1760-1771.

Lopez del Amo JM, Fink U, Dasari M, Grelle G, Wanker EE, Bieschke J, Reif B. 2012. Structural properties of EGCGinduced, nontoxic Alzheimer's disease $A \beta$ oligomers. J Mol Biol 421: 517-524.

Lu JX, Qiang W, Yau WM, Schwieters CD, Meredith SC, Tycko R. 2013. Molecular structure of $\beta$-amyloid fibrils in Alzheimer's disease brain tissue. Cell 154: 1257-1268.

Lührs T, Ritter C, Adrian M, Riek-Loher D, Bohrmann B, Döbeli H, Schubert D, Riek R. 2005. 3D structure of Alzheimer's amyloid- $\beta(1-42)$ fibrils. Proc Natl Acad Sci 102: $17342-17347$.

Margittai M, Langen R. 2008. Fibrils with parallel in-register structure constitute a major class of amyloid fibrils: $\mathrm{Mo}-$ lecular insights from electron paramagnetic resonance spectroscopy. Q Rev Biophys 41: 265-297.

McDonald M, Box H, Bian W, Kendall A, Tycko R, Stubbs G. 2012. Fiber diffraction data indicate a hollow core for the Alzheimer's A 3 3-fold symmetric fibril. J Mol Biol 423: 454-461.

Meinhardt J, Sachse C, Hortschansky P, Grigorieff N, Fändrich M. 2009. $A \beta(1-40)$ fibril polymorphism implies diverse interaction patterns in amyloid fibrils. J Mol Biol 386: $869-877$.

Nelson R, Sawaya MR, Balbirnie M, Madsen AØ, Riekel C, Grothe R, Eisenberg D. 2005. Structure of the cross- $\beta$ spine of amyloid-like fibrils. Nature 435: 773-778.

Olofsson A, Lindhagen-Persson M, Sauer-Eriksson AE, Öhman A. 2007. Amide solvent protection analysis demonstrates that amyloid- $\beta(1-40)$ and amyloid- $\beta(1-42)$ form different fibrillar structures under identical conditions. Biochem J 404: 63-70.

Paravastu AK, Leapman RD, Yau WM, Tycko R. 2008. Molecular structural basis for polymorphism in Alzheimer's $\beta$-amyloid fibrils. Proc Natl Acad Sci 105: 18349-18354.

Paravastu AK, Qahwash I, Leapman RD, Meredith SC, Tycko R. 2009. Seeded growth of $\beta$-amyloid fibrils from Alzheimer's brain-derived fibrils produces a distinct fibril structure. Proc Natl Acad Sci 106: 7443-7448. 
Parthasarathy S, Inoue M, Xiao YL, Matsumura Y, Nabeshima Y, Hoshi M, Ishii Y. 2015. Structural insight into an Alzheimer's brain-derived spherical assembly of amyloid $\beta$ by solid-state NMR. J Am Chem Soc 137: 64806483.

Pensalfini A, Albay R, Rasool S, Wu JW, Hatami A, Arai H, Margol L, Milton S, Poon WW, Corrada MM, et al. 2014 Intracellular amyloid and the neuronal origin of Alzheimer neuritic plaques. Neurobiol Dis 71: 53-61.

Petkova AT, Ishii Y, Balbach JJ, Antzutkin ON, Leapman RD, Delaglio F, Tycko R. 2002. A structural model for Alzheimer's $\beta$-amyloid fibrils based on experimental constraints from solid state NMR. Proc Natl Acad Sci 99: 16742-16747.

Petkova AT, Buntkowsky G, Dyda F, Leapman RD, Yau WM Tycko R. 2004. Solid state NMR reveals a pH-dependent antiparallel $\beta$-sheet registry in fibrils formed by a $\beta$-amyloid peptide. J Mol Biol 335: 247-260.

Petkova AT, Leapman RD, Guo ZH, Yau WM, Mattson MP, Tycko R. 2005. Self-propagating, molecular-level polymorphism in Alzheimer's $\beta$-amyloid fibrils. Science 307: 262-265.

Petkova AT, Yau WM, Tycko R. 2006. Experimental constraints on quaternary structure in Alzheimer's $\beta$-amyloid fibrils. Biochemistry 45: 498-512.

Potapov A, Yau WM, Ghirlando R, Thurber KR, Tycko R. 2015 . Successive stages of amyloid- $\beta$ self-assembly characterized by solid state nuclear magnetic resonance with dynamic nuclear polarization. J Am Chem Soc 137: 8294 8307.

Qiang W, Yau WM, Tycko R. 2011. Structural evolution of Iowa mutant $\beta$-amyloid fibrils from polymorphic to homogeneous states under repeated seeded growth. J Am Chem Soc 133: 4018-4029.

Qiang W, Yau WM, Luo YQ, Mattson MP, Tycko R. 2012. Antiparallel $\beta$-sheet architecture in Iowa-mutant $\beta$ amyloid fibrils. Proc Natl Acad Sci 109: 4443-4448.

Qiang W, Kelley K, Tycko R. 2013. Polymorph-specific kinetics and thermodynamics of $\beta$-amyloid fibril growth. J Am Chem Soc 135: 6860-6871.

Raleigh DP, Levitt MH, Griffin RG. 1988. Rotational resonance in solid state NMR. Chem Phys Lett 146: 71-76.

Sandberg A, Luheshi LM, Sollvander S, de Barros TP, Macao B, Knowles TPJ, Biverstal H, Lendel C, Ekholm-Petterson F, Dubnovitsky A, et al. 2010. Stabilization of neurotoxic Alzheimer amyloid- $\beta$ oligomers by protein engineering. Proc Natl Acad Sci 107: 15595-15600.

Sarkar B, Mithu VS, Chandra B, Mandal A, Chandrakesan M, Bhowmik D, Madhu PK, Maiti S. 2014. Significant structural differences between transient amyloid- $\beta$ oligomers and less-toxic fibrils in regions known to harbor familial Alzheimer's mutations. Angew Chem Int Ed Engl 53: 6888-6892.

Sawaya MR, Sambashivan S, Nelson R, Ivanova MI, Sievers SA, Apostol MI, Thompson MJ, Balbirnie M, Wiltzius JJW, McFarlane HT, et al. 2007. Atomic structures of amyloid cross- $\beta$ spines reveal varied steric zippers. $\mathrm{Na}$ ture 447: 453-457.

Scheidt HA, Morgado I, Rothemund S, Huster D, Fändrich M. 2011. Solid state NMR spectroscopic investigation of a $\beta$ protofibrils: Implication of $A \beta$-sheet remodeling upon maturation into terminal amyloid fibrils. Angew Chem Int Ed Engl 50: 2837-2840.

Scheidt HA, Morgado I, Huster D. 2012. Solid state NMR reveals a close structural relationship between amyloid- $\beta$ protofibrils and oligomers. J Biol Chem 287: 2282222826.

Schütz AK, Vagt T, Huber M, Ovchinnikova OY, Cadalbert R, Wall J, Güntert P, Böckmann A, Glockshuber R, Meier BH. 2014. Atomic-resolution three-dimensional structure of amyloid $\beta$ fibrils bearing the Osaka mutation. Angew Chem Int Ed Engl 53: 1-6.

Sgourakis NG, Yau WM, Qiang W. 2015. Modeling an inregister, parallel "Iowa" $A \beta$ fibril structure using solid state NMR data from labeled samples with Rosetta. Structure 23: 216-227.

Stöhr J, Condello C, Watts JC, Bloch L, Oehler A, Nick M, DeArmond SJ, Giles K, DeGrado WF, Prusiner SB. 2014. Distinct synthetic $A \beta$ prion strains producing different amyloid deposits in bigenic mice. Proc Natl Acad Sci 111: 10329-10334.

Tay WM, Huang DT, Rosenberry TL, Paravastu AK. 2013. The Alzheimer's amyloid- $\beta(1-42)$ peptide forms offpathway oligomers and fibrils that are distinguished structurally by intermolecular organization. J Mol Biol 425: 2494-2508.

Tjernberg LO, Callaway DJ, Tjernberg A, Hahne S, Lilliehöök C, Terenius L, Thyberg J, Nordstedt C. 1999. A molecular model of Alzheimer amyloid $\beta$-peptide fibril formation. J Biol Chem 274: 12619-12625.

Tomic JL, Pensalfini A, Head E, Glabe CG. 2009. Soluble fibrillar oligomer levels are elevated in Alzheimer's disease brain and correlate with cognitive dysfunction. $\mathrm{Neu}$ robiol Dis 35: 352-358.

Tomiyama T, Nagata T, Shimada H, Teraoka R, Fukushima A, Kanemitsu H, Takuma H, Kuwano R, Imagawa M, Ataka $S$, et al. 2008. A new amyloid- $\beta$ variant favoring oligomerization in Alzheimer's-type dementia. Ann Neurol 63: 377-387.

Török M, Milton S, Kayed R, Wu P, McIntire T, Glabe CG, Langen R. 2002. Structural and dynamic features of Alzheimer's $A \beta$ peptide in amyloid fibrils studied by sitedirected spin labeling. J Biol Chem 277: 40810-40815.

Tycko R. 2007. Symmetry-based constant-time homonuclear dipolar recoupling in solid state NMR. J Chem Phys 126: 064506

Tycko R. 2014. Physical and structural basis for polymorphism in amyloid fibrils. Prot Sci 23: 1528-1539.

Tycko R, Dabbagh G. 1990. Measurement of nuclear magnetic dipole-dipole couplings in magic angle spinning NMR. Chem Phys Lett 173: 461-465.

Tycko R, Wickner RB. 2013. Molecular structures of amyloid and prion fibrils: Consensus versus controversy. Acc Chem Res 46: 1487-1496.

Tycko R, Sciarretta KL, Orgel J, Meredith SC. 2009. Evidence for novel $\beta$-sheet structures in Iowa mutant $\beta$-amyloid fibrils. Biochemistry 48: 6072-6084.

Van Melckebeke H, Wasmer C, Lange A, Ab E, Loquet A, Böckmann A, Meier BH. 2010. Atomic-resolution threedimensional structure of HET-s(218-289) amyloid fibrils by solid state NMR spectroscopy. J Am Chem Soc 132: 13765-13775. 
Walsh DM, Klyubin I, Fadeeva JV, Cullen WK, Anwyl R, Wolfe MS, Rowan MJ, Selkoe DJ. 2002. Naturally secreted oligomers of amyloid $\beta$ protein potently inhibit hippocampal long-term potentiation in vivo. Nature 416: 535-539.

Watts JC, Condello C, Stöhr J, Oehler A, Lee J, DeArmond SJ, Lannfelt L, Ingelsson M, Giles K, Prusiner SB. 2014 Serial propagation of distinct strains of $A \beta$ prions from Alzheimer's disease patients. Proc Natl Acad Sci 111: $10323-10328$.

Williams AD, Sega M, Chen ML, Kheterpal I, Geva M, Berthelier V, Kaleta DT, Cook KD, Wetzel R. 2005. Structural properties of $A \beta$ protofibrils stabilized by a small molecule. Proc Natl Acad Sci 102: 7115-7120.

Wong DF, Rosenberg PB, Zhou Y, Kumar A, Raymont V, Ravert HT, Dannals RF, Nandi A, Brasic JR, Ye WG, et al. 2010. In vivo imaging of amyloid deposition in Alzheimer disease using the radioligand ${ }^{18} \mathrm{~F}-\mathrm{AV}-45$ ( florbetapir F 18). J Nucl Med 51: 913-920.

Wu JW, Breydo L, Isas JM, Lee J, Kuznetsov YG, Langen R, Glabe C. 2010. Fibrillar oligomers nucleate the oligomerization of monomeric amyloid $\beta$ but do not seed fibril formation. J Biol Chem 285: 6071-6079.

Xiao YL, Ma BY, McElheny D, Parthasarathy S, Long F, Hoshi M, Nussinov R, Ishii Y. 2015. A $\beta(1-42)$ fibril structure illuminates self-recognition and replication of amyloid in Alzheimer's disease. Nat Struct Mol Biol 22: 499-505.

Yu LP, Edalji R, Harlan JE, Holzman TF, Lopez AP, Labkovsky B, Hillen H, Barghorn S, Ebert U, Richardson PL, et al. 2009. Structural characterization of a soluble amyloid $\beta$-peptide oligomer. Biochemistry 48: 1870-1877. 


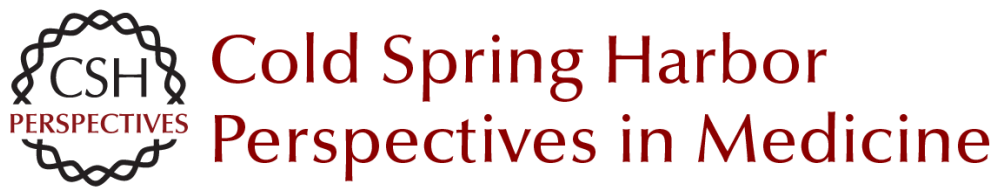

\title{
Molecular Structure of Aggregated Amyloid- $\beta$ : Insights from Solid-State Nuclear Magnetic Resonance
}

\author{
Robert Tycko
}

Cold Spring Harb Perspect Med 2016; doi: 10.1101/cshperspect.a024083

\section{Subject Collection Prion Diseases}

TDP-43 Prions

Takashi Nonaka and Masato Hasegawa

$\alpha$-Synuclein: Multiple System Atrophy Prions Amanda L. Woerman, Joel C. Watts, Atsushi Aoyagi, et al.

Genetics of Synucleinopathies Robert L. Nussbaum

$\beta$-Amyloid Prions and the Pathobiology of

Alzheimer's Disease Joel C. Watts and Stanley B. Prusiner

Disease Mechanisms of C9ORF72 Repeat

Expansions

Tania F. Gendron and Leonard Petrucelli

Chronic Traumatic Encephalopathy: Is Latency in Symptom Onset Explained by Tau Propagation? Joshua Kriegel, Zachary Papadopoulos and Ann C. McKee

Noncerebral Amyloidoses: Aspects on Seeding, Cross-Seeding, and Transmission Gunilla T. Westermark, Marcus Fändrich, Katarzyna Lundmark, et al.

Structural and Chemical Biology of Presenilin Complexes

Douglas S. Johnson, Yue-Ming Li, Martin

Pettersson, et al.
Cell Biology and Pathophysiology of $\alpha$-Synuclein Jacqueline Burré, Manu Sharma and Thomas C. Südhof

Molecular Mechanisms of Chronic Wasting

Disease Prion Propagation Julie A. Moreno and Glenn C. Telling

Genetics of Amyotrophic Lateral Sclerosis Mehdi Ghasemi and Robert H. Brown, Jr.

The Genetics of C9orf72 Expansions Ilse Gijselinck, Marc Cruts and Christine Van Broeckhoven

Prion-Like Characteristics of

Polyglutamine-Containing Proteins Margaret M.P. Pearce and Ron R. Kopito

Therapeutic Strategies for Restoring Tau Homeostasis

Zapporah T. Young, Sue Ann Mok and Jason E. Gestwicki

Fused in Sarcoma Neuropathology in Neurodegenerative Disease lan R.A. Mackenzie and Manuela Neumann

Experimental Models of Inherited PrP Prion Diseases Joel C. Watts and Stanley B. Prusiner

For additional articles in this collection, see http://perspectivesinmedicine.cshlp.org/cgi/collection/ 